\title{
Three species of Pedicularis L. (Orobanchaceae) new to China found in Xinjiang
}

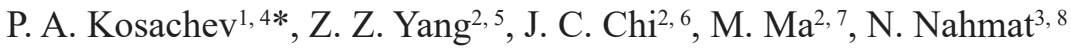 \\ ${ }^{1}$ South Siberian Botanical Garden, Altai State University, Lenina pr., 61, Barnaul, 656049, Russian Federation \\ ${ }^{2}$ Yang's Herbarium, Urumqi, Xinjiang, 830011, China \\ ${ }^{3}$ Autonomous Region-level Agricultural Science and Technology Park Management Committee of \\ Zhaosu County, Zhaosu, Xinjiang, 835600, China \\ ${ }^{4}$ E-mail: pakosachev@yandex.ru; ORCID iD: https://orcid.org/0000-0002-4087-6336 \\ ${ }^{5}$ ORCID iD: https://orcid.org/0000-0003-3618-6970 \\ ${ }^{6}$ ORCID iD: https://orcid.org/0000-0002-7849-1087 \\ ${ }^{7}$ ORCID iD: https://orcid.org/0000-0001-7295-3781 \\ ${ }^{8}$ ORCID iD: https://orcid.org/0000-0002-5569-3153 \\ * Corresponding author
}

Keywords: flora of China, new records, Pedicularis alatauica, Pedicularis compacta, Pedicularis pubiflora, typification, Xinjiang.

Summary. Three Pedicularis L. species, P. alatauica Stadlm. ex Vved., P. compacta Steph. ex Willd. and P. pubiflora Vved. (Orobanchaceae), are newly recorded from China. The name Pedicularis compacta is typified and the data on the types of the other two species are given. Comments on important taxonomic features and related species are provided; the distribution map in Xinjiang is given, and the general distribution is outlined.

\section{Три новых для Китая вида мытника (Pedicularis L., Orobanchaceae), собранных в Синьцзяне}

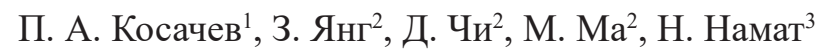 \\ ${ }^{1}$ Южно-Сибирский ботанический сад, Алтайский государственный университет, \\ просп. Ленина, 61, г. Барнаул, 656049, Россия \\ ${ }^{2}$ Гербарий YANG, Урумчи, Синьизян, 830011, Китай
}

${ }^{3}$ Комитет по управлению сельскохозяйственным научно-техническим парком автономного округа Чжаосу, Чжаосу, Синьизян, 835600, Китай

Ключевые слова: типификация, флора Китая, флористические находки, Pedicularis alatauica, Pedicularis compacta, Pedicularis pubiflora.

Аннотация. В статье представлены три новых для флоры Китая вида из рода Pedicularis L. (Pedicularis alatauica Stadlm. ex Vved., P. compacta Steph. ex Willd. и P. pubiflora Vved.), обнаруженные в Синьцзян-Уйгур- 
ском автономном районе. Осуществлена типификация названия Pedicularis compacta и приведены данные о типах двух других видов, а также комментарии о важных таксономических признаках и родственных видах. Дана карта распространения видов в Синьцзяне, а также общее распространение.

The genus Pedicularis L. (Orobanchaceae) with 673 species in the world (POWO, 2021) is widely distributed in high mountains and high latitudes in the Northern Hemisphere. There are 352 species in China (271 species are endemic), and HimalayaHengduan mountain region is the center of origin and species diversity of the genus (Hong, 1983; Yang et al., 1998).

Revision of collections of the joint Sino-Russian Altai expedition of 2007 along with the gatherings of the present authors (except for P. A. K.) of 20192020 revealed that three species of Pedicularis have not been recorded in the flora of China yet, as confirmed by a careful check of relevant literature (Vvedensky, 1955; Ajdarova, 1962; Tsoong, 1963; Semiotrocheva, 1965; Ivanina, 1970; Yang et al., 1998; Mijit, Pan, 2004; Kosachev, 2016). The voucher specimens are deposited in the herbaria of Beijing Normal University (BNU), Altai State University (ALTB) and Institute of Botany of the Chinese Academy of Sciences (PE). For each species, citation of the primary source, protologue and type, characteristic habitats, comments on important taxonomic features and related species, and general distribution are provided.

1. Pedicularis pubiflora Vved., 1955, in Fl. URSS, 22: 754, 812. - P. songarica auct. non Schrenk: Tsoong, 1963, Fl. R. P. Sin. 68: 226, p. p., quoad pl. e Tian-Schan.

Type: "Kirghizia, Tian-Schan centralis, inter lapides ad trajectum Aktasch in montibus Sonkultau, 22 VII 1926, Leg. M. Sovetkina et M. Uspenskaja" (TASH, iso - FRU, K, LE, MW) (Fig. 2).

New locality: "China, Xinjiang, Ili Kazakh Autonomous Prefecture, Zhaosu County, in alpine and subalpine meadows. $42^{\circ} 30^{\prime} 75^{\prime \prime} \mathrm{N}, 81^{\circ} 08^{\prime} 51^{\prime \prime} \mathrm{E}$. 26 V 2020. J. Chi, N. Nahmat 3105 and 3110" (BNU) (Fig. 1).

Ecology and phenology. Alpine and subalpine meadows, among rocks and rubbles. Flowering: May-July. Fruiting: July-August.

Distribution: China, Kazakhstan, Kyrgyzstan, ?Tajikistan and Uzbekistan (a finding on Turkestan and Alai ridges is possible ( $\mathrm{Li}, 1987)$ ).

Note. Pedicularis pubiflora is close to P. songarica Schrenk and $P$. alatauica. From the prior, it differs by a short pubescent corolla. From the latter, P. pubiflora differs in pale yellow (not purple) flowers sometimes with purple spots or veins or teeth of the upper lip; herbaceous (vs. almost webbed) calyx; the calyx teeth 2-3 (not 4) times shorter than the calyx tube; the lower lip slightly smaller than the upper lip (Fig. 3A-D).

As L. I. Ivanina (1970) indicated, this species was reported for the China by P. C. Tsoong (1963) in part under the name $P$. songarica. Besides, A. I. Vvedensky (1955) and then R. A. Ajdarova (1962) indicated the species for the territory of China (Ghulja or Yining), but this was not reflected in the Chinese accounts.

A. I. Vvedensky (1961) and A. A. Konnov (1986) did not cite the species for the floras of Uzbekistan and Tajikistan, but A. D. Li (1989) mentioned this species for the Turkestan (Turkestansky) and Alai (Alaysky) ranges located on the territory of these states. Therefore, the presence of the species in Uzbekistan and Tajikistan can be admitted.

2. Pedicularis alatauica Stadlm. ex Vved., 1955, Fl. USSR, 22: 813, 755. - P. alatauica Stadlm. ex Limpr. 1924, in Feddes Repert. 20: 265, nom. nud. - P. almaatensis M. Pop. 1940, in Trudy Almaatinskogo Zapovednika, 3: 42, nom. nud.

Type: “№ 672. Alatau transiliensis: in valle fl. Kaschkelen, reg. alp. 1896 VI 21, leg. V. F. Brotherus" (H) (Fig. 4).

New locality: "China, Xinjiang, Ili Kazakh Autonomous Prefecture, Zhaosu County, in dry slopes and alpine region. $43^{\circ} 16^{\prime} 2^{\prime \prime} \mathrm{N}, 81^{\circ} 15^{\prime} 4^{\prime \prime} \mathrm{E} .27$ V 2020. J. Chi, N. Nahmat 3212 and 3214" (BNU) (Fig. 1).

Ecology and phenology. Dry slopes and rocks in the alpine belt. Flowering: May-July. Fruiting: JulyAugust.

Distribution: China, Kazakhstan, Kyrgyzstan, Tajikistan.

Note. From the superficially close $P$. songarica, it differs by a short pubescent and pink corolla (Fig. $3 \mathrm{E}-\mathrm{H})$.

A. I. Vvedensky (1955) indicated the species for the Eastern Tian Shan. However, until this study, this indication was questionable (Kosachev, 2016).

3. Pedicularis compacta Steph. ex Willd. 1800, Sp. P1. 3, 1: 219. 


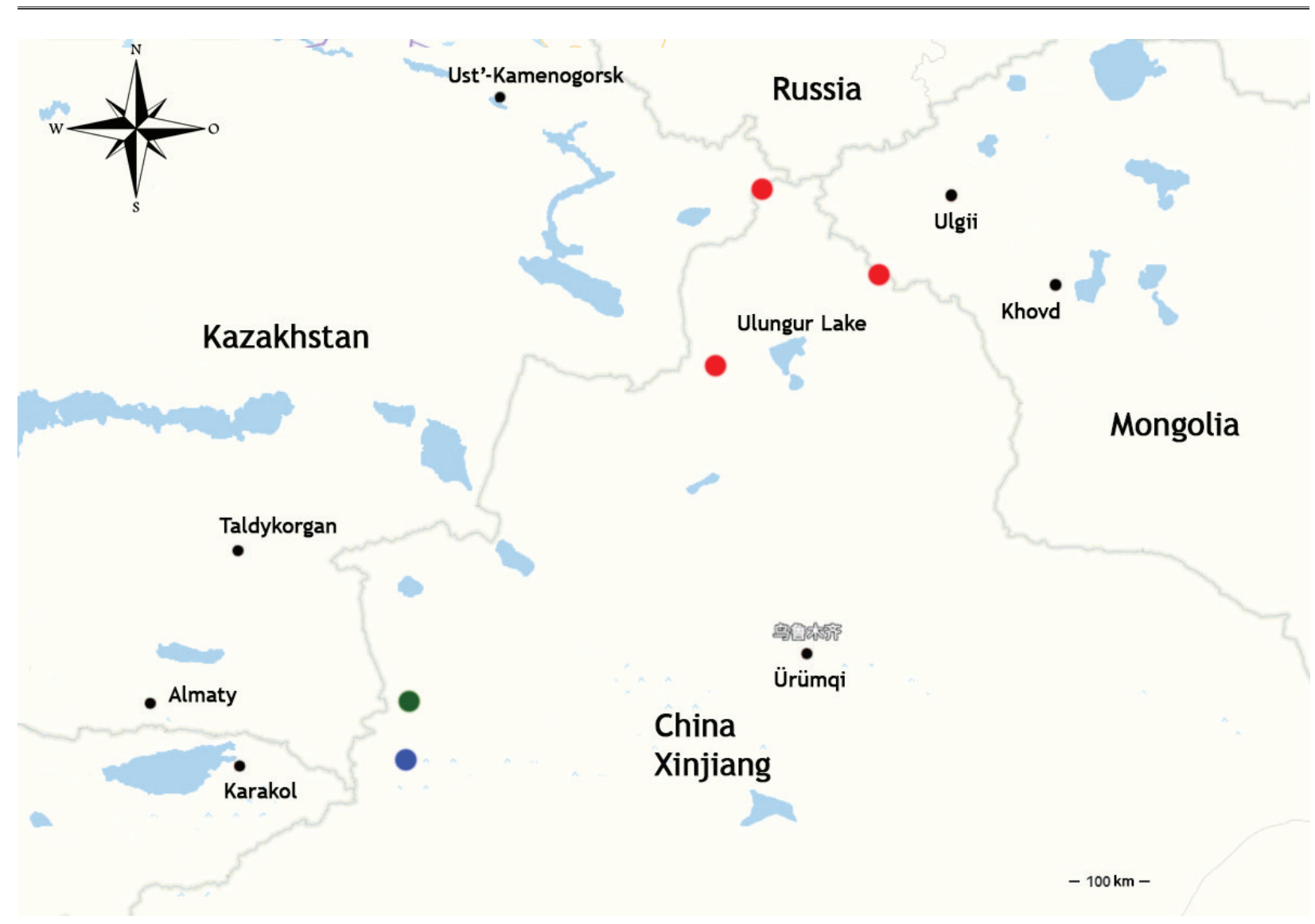

Fig. 1. The new floristic findings of Pedicularis L. in Xinjiang, China.

- Pedicularis pubiflora
- P. alatanica
- P. compacta

Protologue: "in Sibiriae pratis".

Lectotype (designated here) or holotype: "Habitat in pratis Sibiriae" (B: B-W 11220010).

Note. Only one herbarium sheet from the BerlinDahlem Museum (B) is known, which refers to the type material. It is signed with the name Stephan and the letter "W", indicating the Willdenow's Herbarium. Since there is no certainty that no other original specimens existed that could be later used by Willdenow for exchange with colleagues, here we designate is as lectotype of the name $P$. compacta.

Ecology and phenology. Moss and shrub tundra, meadows, moist woodlands in the high-mountain belt; occasionally streamsides in the upper portion of the forest belt. Flowering: June to August. Fruiting: July to September.

Distribution: China, Kazakhstan (Altai), Mongolia (northern, north-western and central parts), Russia (north of the European part, Ural Mountains, Western and Eastern Siberia).

New localities:

1. "China, Xinjiang, Hoboksar, in shrubs and subalpine grassy slopes. $47^{\circ} 07^{\prime} 47^{\prime \prime} \mathrm{N}, 86^{\circ} 06^{\prime} 44^{\prime \prime} \mathrm{E}$.
15 VII 2019. Z. Yang, M. Ma, 2377 and 2380" (BNU).

2. "China, Xinjiang, Fuhai county, Mongolian Altai, upper reaches of Yelt-gol in $15 \mathrm{~km}$ upper the mouth of Dudtsa-he, Kungeytytau mts., $48^{\circ} 03^{\prime} 36.8^{\prime \prime} \mathrm{N}, 88^{\circ} 51^{\prime} 25.4^{\prime \prime} \mathrm{E}, 2700-3036 \mathrm{~m}$ a. s. 1. , birch dwarf forest, subalpine and alpine meadows, near the snow, rocks, steppe slopes, roadside. 23 VII 2007. S. V. Smirnov, D. A. German, M. G. Kutsev, Wenli Chen, Bing Liu" (ALTB, PE).

3. "China, Xinjiang, Habahe county, South Altai range, south slope, valley of left tributary of AkKaba in $5 \mathrm{~km}$ from the border with Kazakhstan and in $7 \mathrm{~km}$ to NEE of the peak $3030 \mathrm{~m}, 49^{\circ} 01^{\prime} 40.8^{\prime \prime} \mathrm{N}$, $86^{\circ} 50^{\prime} 37.5^{\prime \prime} \mathrm{E}, 1950-2650 \mathrm{~m}$ a. s. 1., subalpine tall and low herb vegetation, degraded alpine meadows, gravely tundra, rocks. 17 VII 2007. S. V. Smirnov, D. A. German, M. G. Kutsev, Wenli Chen, Bing Liu" (ALTB, PE) (Fig. 1).

Note 1. The species was correctly identified by collectors of the Chinese-Russian Altai expedition, but was clearly overlooked when publishing new findings for Xinjiang (German et al., 2012). 


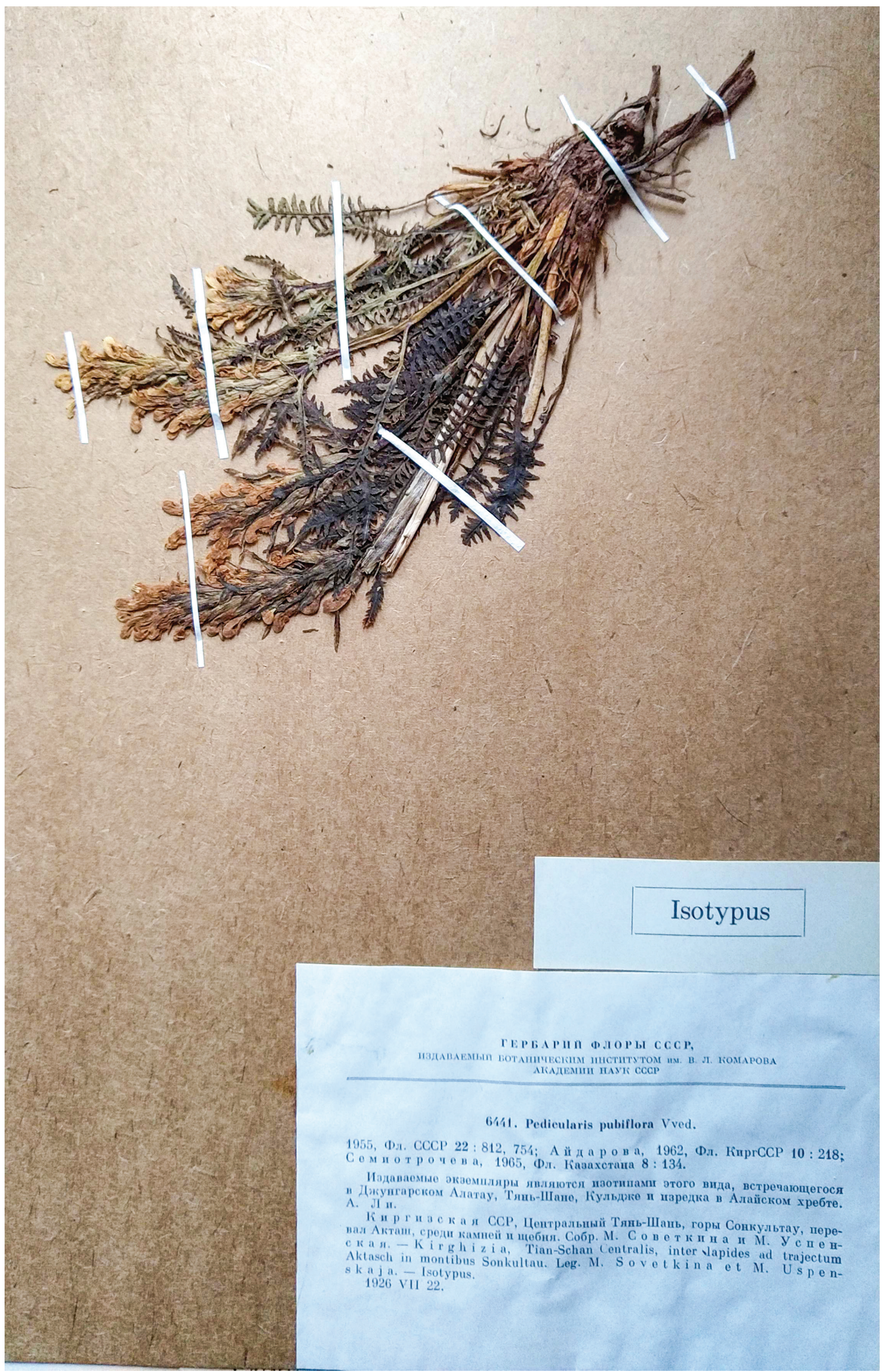

Fig. 2. Isotype of Pedicularis pubiflora Vved. from National Academy of Science, Kyrgyzstan (FRU). 

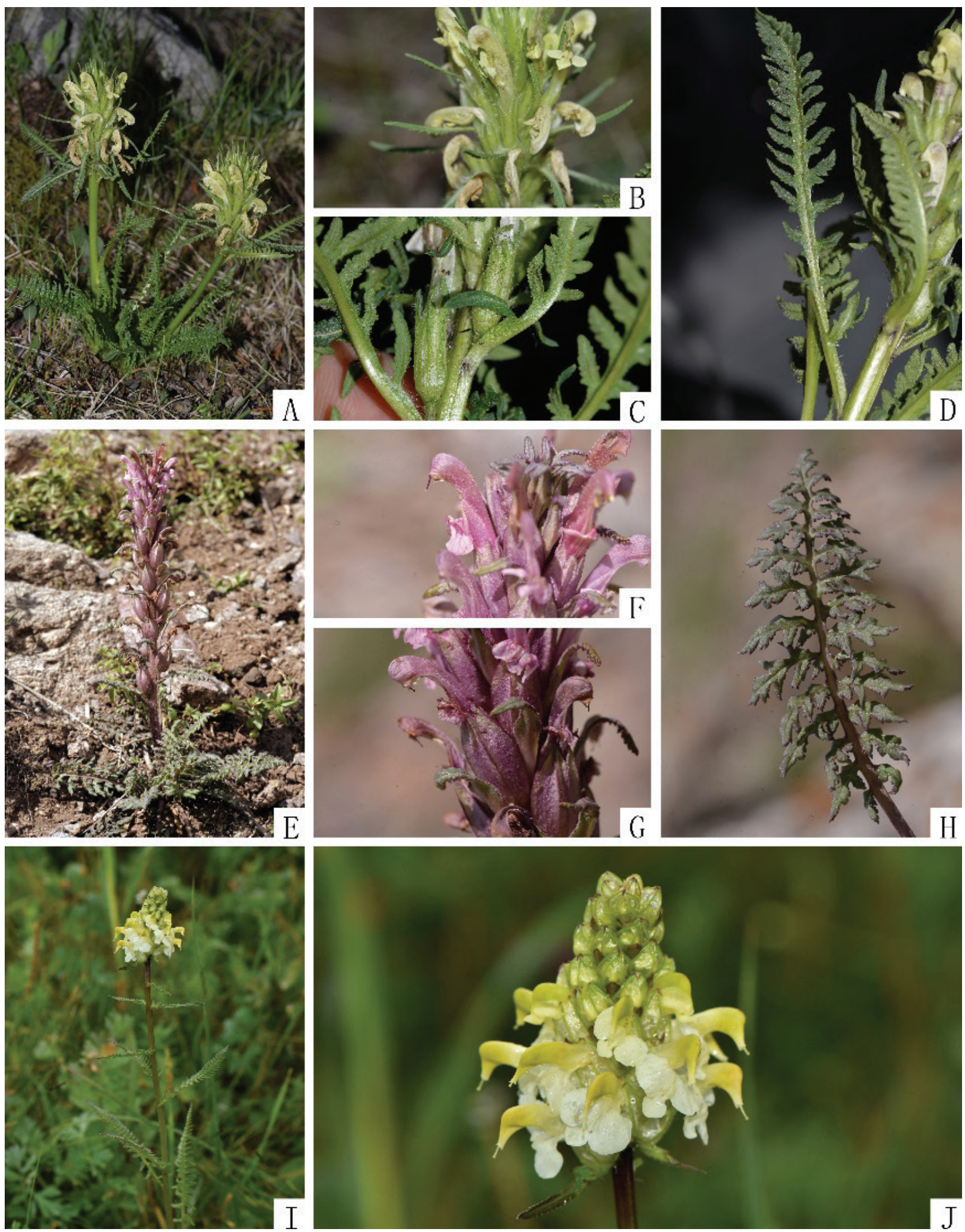

Fig. 3. A-D - Pedicularis pubiflora Vved.: A - Habitat and plants; B - Flowers; C - Calyx; D - Adaxial side view of a leaf. E-H - P. alatauica Stadlm. ex Vved.: E. Habitat and plants; F - Flowers; G - Calyx; H - Adaxial side view of a leaf. I-J - P. compacta Steph. ex Willd.: I - Plants; J - Inflorescence. 


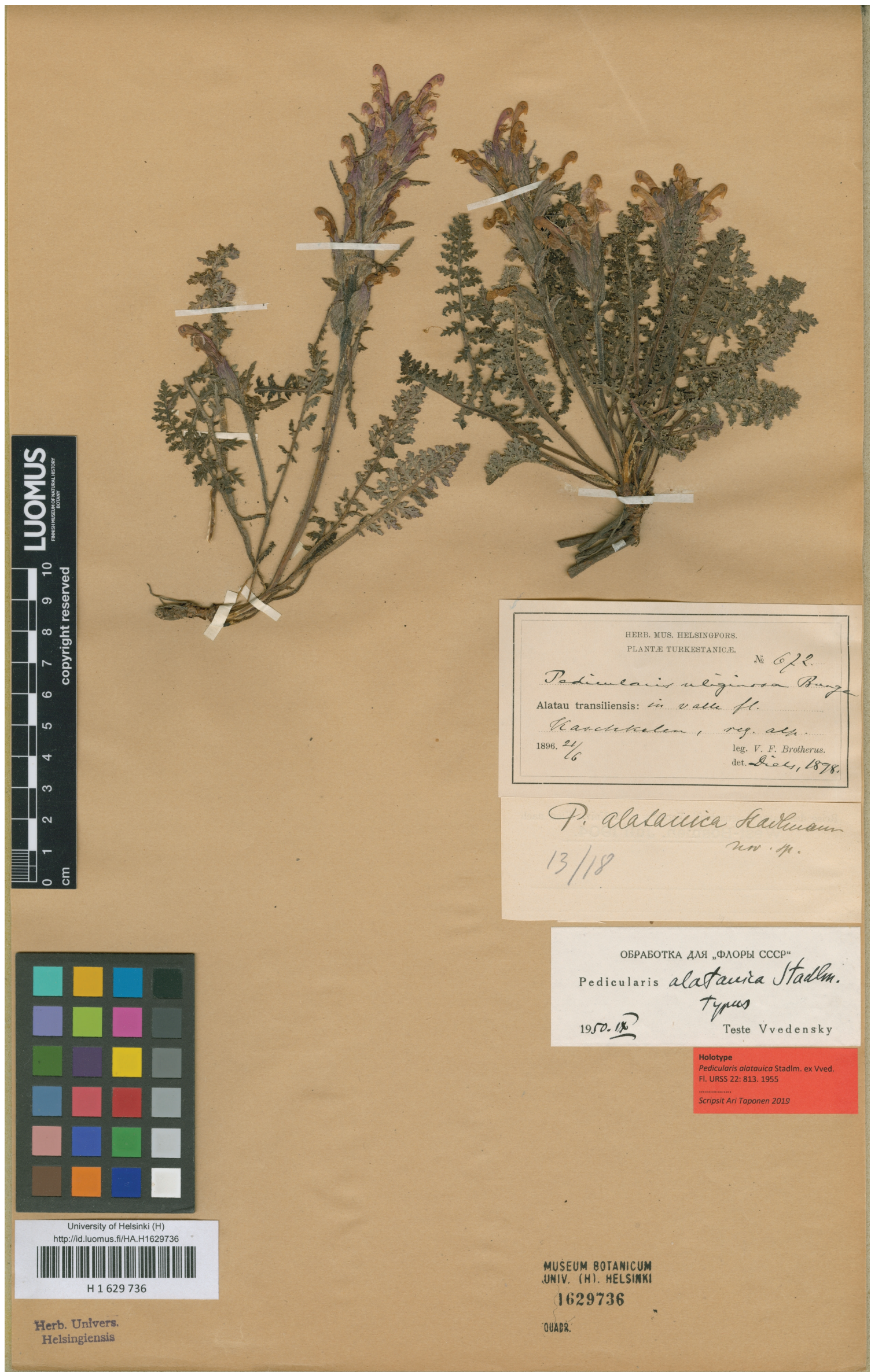

Fig. 4. Holotype of Pedicularis alatauica Stadlm. ex Vved. from University of Helsinki (H1629736). 
Note 2. This finding was quite expected since this species is common in the alpine belt of the Altai Mountain Country (Kosachev, 2016, 2017).

From other related species ( $P$. brachystachys Bunge, $P$. incarnata L. and P. proboscidea Stev.), it is easily distinguished by a compact inflorescence when flowering, a long straight spout that departs from the helmet at an angle of 90 degrees, the corolla tube also bent almost at right angles, as well as a webbed (not herbaceous) calyx, clearly visible in the fruit.

\section{Acknowledgements}

We express our sincere gratitude to Alexander Sennikov, Curator of Botany Unit (University of Helsinki), for providing a scanned image of the holotype of Pediculatis alatauica.

\section{REFERENCES / ЛИTEPATУPA}

Ajdarova R. A. 1962. Pedicularis L. In: Flora Kirgizskoy SSR [Flora of Kyrgyzstan]. Vol. 10. Frunze: Izdatelstvo AN Kirgizskoy SSR. Pp. 197-227. [In Russian] (Aйдарова P. A. Род Мытник-Pedicularis L. // Флора Киргизской ССР. Т. 10. Фрунзе: Изд-во АН Киргизской ССР, 1962. С. 197-227).

German D. A., Chen Wen-Li, Smirnov S. V., Liu B., Kutzev M. G., Wang J., Shmakov A. I. Kamelin R. V. 2012. Plant genera and species new to China recently found in northwest Xinjiang. Nordic Journal of Botany 30: 61-69.

Hong D. 1983. The distribution of Scrophulariaceae in the Holarctic with special reference to the floristic relationships between eastern Asia and eastern North America. Ann. Miss. Bot. Gard., 70: 701-713.

Ivanina L. I. 1970. Pedicularis L. In: Plantae Asiae Centralis. Fasc. 5. Leningrad: Nauka. Pp. 148-188.

Konnov A. A. 1986. Pedicularis L. In: Flora Tadzhikskoy SSR [Flora of Tajikistan]. Vol. 8. T. F. Kochkareva (Ed.). Leningrad: Nauka, Leningradskoye otdeleniye. Pp. 407-426. [In Russian] (Коннов A. A. Мытник-Pedicularis L. // Флора Таджикской ССР. Т. 8. Ред. Т. Ф. Кочкарева. Л.: Наука. Ленинградское отд-е, 1986. С. 407-426).

Kosachev P. A. 2016. The system and conspectus of the genus Pedicularis (Orobanchaceae) of Altay mountains and Tian Shan. Biological Bulletin of Bogdan Chmelnitskiy Melitopol State Pedagogical University 6(1): 115-166.

Kosachev P. A. 2017. Check-list of Scrophulariaceae Juss. s. 1. of North Asia. Acta Biologica Sibirica (3)4: 31-76. [In Russian] (Косачев П. А. Конспект сем. Scrophulariaceae Juss. s. 1. Северной Азии // Acta Biologica Sibirica, 2017. T.3, №. 4. C. 31-76). DOI: $10.14258 /$ abs.v3i4.3631

Li A. D. 1987. Pedicularis L. In: Conspectus Florae Asiae Mediae. T. 9. Taschkent: editio Academiae scientiarium UzSSR. Pp. 254-269. [In Russian] (Ли А. Д. Род 912. (24). Pedicularis L. - Мытник // Определитель растений Средней Азии. Т. 9. Ташкент: Изд-во «ФАН» Узбекской ССР, 1987. С. 254-269).

Mijit H., Pan X-L. 2004. Pedicularis. In: Flora Xinjiangensis. Vol. 4. Ürümqi: Xinjiang Sciences and Technology Publishing House. Pp. 409-421.

Pedicularis compacta / Curators Herbarium B (2000+). Digital specimen images at the Herbarium Berolinense. [Dataset]. Version: 09 Feb 2021. Data Publisher: Botanic Garden and Botanical Museum Berlin. http://ww2.bgbm. org/herbarium/

POWO [2021]. Plants of the World Online. Royal Botanic Gardens, Kew. Available from: http://www. plantsoftheworldonline.org/ (Accessed 07 February 2021).

Semiotrocheva N. L. 1965. Pedicularis. In: Flora Kazakhstana [Flora of Kazakhstan]. Vol. 8. Alma-Ata: Nauka. Pp. 115-145. [In Russian] (Семиотрочева Н. Л. Род Мытник - Pedicularis L. // Флора Казахстана. Т. 8. АлмаАта: Наука, 1965. С. 115-145).

Tsoong P. C. 1963. Pedicularis L. In: Flora Reipublicae Popularis Sinicae. Vol. 8. Beijing: Science Press. Pp. $1-378$.

Vvedensky A. I. 1955. Pedicularis L. In: Flora USSR [Flora of USSR]. Vol. 22. Ed. by V. L. Komarov. Moscow, Leningrad: Academy of Sciences of the USSR. Pp. 115-145. [In Russian] (Введенский А. И. Род МытникPedicularis L. // Флора СССР. Т. 22. Отв. ред. В. Л. Комаров. М.-Л.: Изд-во АН СССР, 1955. С. 687-795).

Vvedensky A. I. 1961. Scrophulariaceae. In: Flora Uzbekistana [Flora Uzbekistanica]. T. 5. A. I. Vvedensky (Ed.). Taschkent: Editio Academiae scientiarium UzSSR. Pp. 447-498. [In Russian] (Введенский А. И. Сем. CXXV. Scrophulariaceae - Норичниковые // Флора Узбекистана. Т. 5. Ред. А. И. Введенский. Ташкент: Изд-во АН Узбекской ССР, 1961. С. 447-498.

Yang H-B, Holmgren H. N., Mill R. R. 1998. Pedicularis. In: Flora of China. Vol. 18. Beijing: Science Press and St. Louis: Missouri Botanical Garden Press. Pp. 97-209. 